\section{THE INVENTIONS EXHIBITION}

$\mathrm{T} N$ the presence of a crowded and distinguished assembly the Inventions Exhibition was opened by the Prince of Wales on Monday. The Exhibition is, as usual on first days, still in a somewhat chaotic condition, and we can do no more this week than refer to the leading incidents of the opening ceremony. Sir Frederick Bramwell, Chairman of the Executive Council, in his address to the Prince of Wales, gave a sketch of the progress and objects of the Exhibition, which, he pointed out, is intended to illustrate the progress of inventions since the year 1862 , and that of musical instruments and appliances since the commencement of the present century. The labours of the different committees were, he stated, rendered extremely onerous by the vast number of applications received-a number far greater then we had space to accommodate. Influential Commissions have been nominated by Austria-Hungary, France, China, Greece, Italy, Japan, Russia, Siam, and Switzerland, from which countries interesting and valuable exhibits have been received or are promised. Arrangements have been made with the Council of the Royal Albert Hall by which that building forms an integral portion of the Exhibition, with the National Fish Culture Association for the maintenance of the Aquarium, and with the Council of the Royal Horticultural Society for the holding of the usual periodical flower and fruit shows. The Old London Street, which was so popular a feature in last year's Exhibition, has been maintained. Many small annexes have been swept away, and in their places spacious galleries have been erected. Not only has greater exhibiting space been thus obtained, but the gardens, which are so great a source of attraction to visitors, have actually been enlarged. Notwithstanding the fact that the gallery used last year for machinery has been greatly extended to meet the requirements of exhibitors, it proved to be inadequate for the many important inventions for which motive power was desired; indeed, it has been found necessary to furnish such power in no less than three other galleries. "The employment of electricity for the purposes of lighting," Sir Frederick said, "is undoubtedly one of the most striking instances of the application of science to the purposes of daily life ; we have, therefore, not hesitated to give this subject special prominence. The method we have adopted will, it is believed, render any sudden failure of the lights impossible, and will favourably display the most recent and improved apparatus, and the advances that up to this date have been made in electric lighting. After most careful experiments we have ventured to employ, for the garden illumination, the incandescent electric lamp, and we have done so in a manner and on a scale which, we believe, has never before been attempted. As a division of the Exhibition is devoted to music, we have set apart an important portion of the buildings to the illustration of instruments and appliances appertaining to that art; and we have invited the formation of a historical loan collection of musical instruments, which we believe is of a deeply interesting character. In requesting your Royal Highness to declare this Exhibition open we desire to express the hope that it may, on the one hand, be the means of bringing valuable and meritorious inventions prominently before the general public, to the benefit and credit of the exhibitors, and that it may, on the other hand, be the means by which that public may, within the area of one exhibition, be enabled to appreciate the marvellous progress which during the past quarter of a century every industry has achieved."

The Prince of Wales, in reply said: It is with much pleasure that I have listened to the report of the Executive Council, and I fully appreciate the labours which you have bestowed upon this great undertaking. At the closing of the International Fisheries Exhibition I took the opportunity of expressing a hope that an International Inventions Exhibition might be held in these buildings during the present year; and I am sincerely gratified to find that this hope has been realised. The scope of this Exhibition is, indeed, vast, and I can readily comprehend the difficulties which must have beset you and the Committee of Advice in your endeavours to secure adequate representation for each branch of industry. I have observed with much pleasure that the classification originally adopted has been made the practical basis of the allotment of space in the Exhibition, and that the exhibits in each group have, as far as possible, been placed together. I am convinced that by following this plan you have materially increased the educational value of the Exhibition. I readily echo the sentiments of gratitude which you have expressed for the invaluable aid rendered by the guarantors; and I join with you in welcoming the representatives of those foreign countries who are present here to-day.

The Prince of Wales, after declaring the Exhibition open, made a tour of the galleries in company with the Princess of Wales and many others of the distinguished visitors who were present.

\section{THE FLORA OF BANK-NOTES}

"I A Flore des Billets de Banque" is the title of an article in Science et Nature, an article which, in spite of an amusing tendency inseparable from all things savouring of sensational science, may suggest thoughts more or less alarming in view of recent discoveries in bacteriology. It is no new fact that books, coins, and other articles of a durable nature which pass much from hand to hand may be the means of transmitting

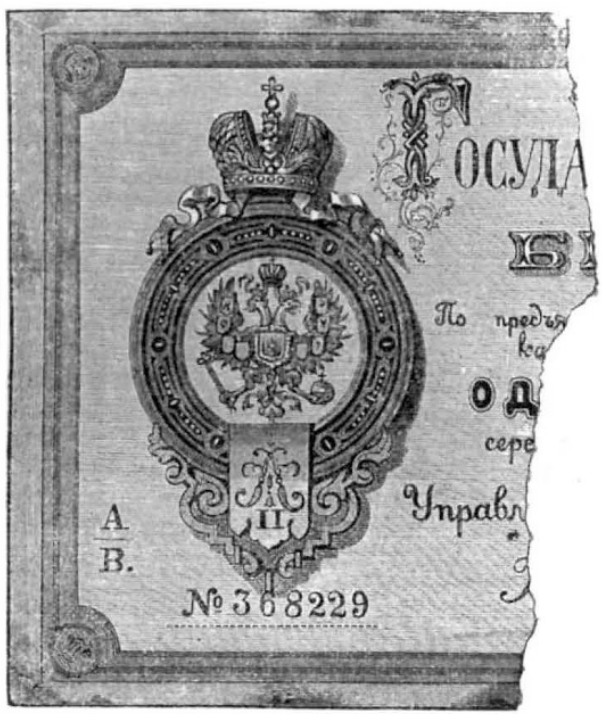

FIG. I

infectious diseases, and if these infectious diseases are caused by visible and tangible agents, it is not going far to expect that the agents should be discoverable on the transmitting media by means of the microscope, and by other methods employed by the specialists who devote themselves to tracing the awful bacterium to its home. Of course it is now matter of fact that "bacteria" (using the term in its widest sense) can be and are causal agents in disease, and the writer of the article referred to shows that bacteria and other minute organisms always occur on bank-notes ; there is, perhaps, no more in this observation than that it demonstrates a fact in a particular case 